CZU 32:342.8

https://doi.org/10.52507/2345-1106.2021-2.11

IMPORTANTุA PROCESULUI ELECTORAL ÎN CADRUL STATULUI DEMOCRATIC

SPRINCEAN Serghei,

doctor habilitat în științe politice, Institutul de Cercetări Juridice, Politice și Sociologice, https://orcid.org/0000-0002-7411-9958

PîRȚAC Grigore,

doctor în științe politice, conferențiar universitar, Universitatea de Studii Europene din Moldova https://orcid.org/0000-0003-3281-3711

MIHALAȘ Victoria,

magistru în drept, Universitatea de Studii Europene din Moldova https://orcid.org/0000-0002-4042-5279

\title{
REZUMAT
}

Importanța modelelor de deliberare în formarea și eficientizarea democratizării politice este crucială în contextul adâncirii crizei globale. În articol sunt evidențiate câteva aspecte importante privind specificul crizei globale contemporane în perspectiva unei mai bune instituționalizări și instrumentalizări a componentelor normative și deliberative-electorale ale democratizării politice. Necesitatea stringentă a depășirii amenințărilor globale imprimă un caracter special proceselor politice precum alegerile sau deliberările publice, creând noi forme de comportament politic. Aceste procese politice trebuie să fie mai bine organizate și mai eficiente în modul de îndeplinire a obiectivelor funcționale ale strategiei de depășire a crizei globale. Diferențele socio-politice, economice, culturale, religioase, etice, mentale sau tehnologic-comunicative, cu impact major asupra standardelor de viață, asupra calității vieții în comunitățile umane care locuiesc pe planeta Pământ, contribuie la întărirea potențialului omenirii de a face față. cu cele mai violente și distructive efecte și rezultate ale crizei globale multidimensionale, prin diversitatea șanselor și identităților pe care le generează. Trebuie respectate, de asemenea, normele morale și legale, pentru a minimiza impactul macro-sistemic al oricăror tipuri de abateri în timpul deliberărilor și alegerilor democratice. În această lucrare se discută și contribuția concepțiilor etice la facilitarea și creșterea libertăţii deliberative, ca condiție de bază a proceselor contemporane de democratizare a societăţii. Amplificarea insecurităţii la scară globală joacă un rol negativ al mediului social-politic advers în progresul democratizării și libertății dezbaterilor politice și alegerilor.

Cuvinte-cheie: democratizare, model de deliberare, dezbateri politice, libertate electorală, securitate globală, insecuritate.

\section{THE IMPORTANCE DELIBERATIVE PRACTICES IN DFEMOCRATISATION OF POLITICS}

SPRINCEAN Serghei,

Doctor habilitate in political science, Institute of Legal, Political and Sociological Research, https://orcid.org/0000-0002-7411-9958

PÎRȚAC Grigore,

$\mathrm{PhD}$ in political science, associate professor, University of European Studies of Moldova https://orcid.org/0000-0003-3281-3711

MIHALAȘ Victoria, Master in Law, University of European Studies of Moldova https://orcid.org/0000-0002-4042-5279 


\section{SUMMARY}

The importance deliberation models in the formation and streamlining of political democratization is crucial in the context of deepening of the global crisis. In the article are emphasized several important aspects regarding the specific of the contemporary global crisis in the perspective of better institutionalization and instrumentalization of normative and deliberation-election components of political democratization. The stringent necessity of overcoming the global menaces imprint a special character to the political processes such as elections or public deliberations, creating new forms of political behavior. These political processes have to be better organized and more efficient in the way to fulfill functional goals of the strategy of overcoming global crisis. The socio-political, economic, cultural, religious, ethical, mental or technological-communicative differences, with a major impact on living standards, on the quality of life standards in human communities inhabiting planet Earth, contribute to the strengthening of mankind's potential to cope with the most violent and destructive effects and results of the multidimensional global crisis, through the diversity of chances and identities it generates. Moral and legal norms must be respected as well, for minimizing the macro-systemic impact of any types of deflections during democratic deliberations and elections. In this piece of work is discussed as well the contribution of ethical conceptions to the facilitation and increasing of the deliberative liberty as a basic condition of the contemporary processes of democratization of the society. Amplifying of the insecurity at global scale plays a negative role of the adverse social-political environment in the progress of democratization and freedom of political debates and elections.

Key-words: democratization, deliberation model, political debates, electoral freedom, global security, insecurity.

Procesele deliberative și electorale ca fenomene sociopolitice complexe, sistematice și etapizate, au ca scop de bază identificarea unor persoane capabile să reprezinte interesele societății în cadrul procedurilor de elaborare, adoptare și implementare a deciziilor politice atât la nivel central, cât și local, sau exprimarea atitudinii față de o chestiune supusă dezbaterii publice [1, p. 78]. Procesul deliberativ constituie esența sistemului democratic de guvernare bazat, în principal, pe selecția și promovarea unei singure soluții din multitudinea variantelor propuse, în virtutea exprimării opiniei majorităţii cetăţenilor cu drept de vot, după cum amintește și savantul american de origine olandeză Arend Lijphart în opera sa „Modele ale democrației” [2, p. 93].

În acest sens, se remarcă necesitatea reconceptualizării problematicii proceselor deliberative şi a rolului acestora pentru buna funcționare a mecanismelor democratice de dirijare socială, mai cu seamă în perioada crizei globale multidimensionale prin care trece omenirea la ora actuală. Astfel, devine important de a evidenția o caracteristică fundamentală, specifică atât sferei sociale și vieții publice, cât și domeniului normelor și standardelor de comportament, și anume - capacitatea de adaptare și raliere a domeniilor vieții sociale la priorităţile stringente și necesităţile majore ale sociumului, cu atât mai mult cu cât pericolele generate de criza globală sunt acum în stadiul de amplificare și prezintă o amenințare importantă nu doar referitor la destabilizarea ordinii mondiale și a sistemelor vieții sociale, precum sistemul politic, economic sau a sistemului valorilor morale tradiționale, dar ridică tot mai multe îndoieli referitor la supraviețuirea speciei umane pe Terra, în condițiile realizării celor mai sumbre scenarii de evoluție a situației din prezent [3, p. 82].

Prin urmare, tendința firească și neintenționată a sistemului social de a se adapta la necesităţile momentului și de a prioritiza, în sensul de ordonare și ierarhizare a scopurilor și obiectivelor pe care și le asumă diverse subsisteme sociale, poate fi sistematizată într-un principiu distinct al prioritizării, ca pilon teoretic în analiza celor mai recente schimbări sociale. Prioritizarea obiectivelor şi deciziilor proxime spre a fi adoptate după o dezbatere se identifică a fi una dintre cele mai complexe aspecte ale structurării obiectului de cercetare, în cazul dezvoltării teoriilor, sau a alegerii corecte a ordinii de sistematizare a priorităților aplicative, în cazul implementării practicilor. Principiul dat poate deveni unul de o importantă crucială pentru practica socială dar și știința contemporană, atât în forma sa teoretică, cât şi în aspectul său aplicativ, dată fiind importanța şi încărcătura sa metodologică. Astfel, acest principiu se manifestă, în egală măsură, în evoluția atât a modelelor deliberative și sistemelor electorale, cât și a sistemelor normative, atât juridice, cât și etice. Reconceptualizarea funcțiilor și importanței modelelor deliberative în condițiile realizării supravieţuirii durabile a omenirii pericolelor globale devine o preocupare majoră a comunității academice în efortul ei de a oferi societății noi explicații ale proceselor sociale contemporane și noi pârghii metodologice şi conceptuale de a direcţiona aceste procese pe o traiectorie favorabilă societății umane la scară mondială [4, p. 72]. Înţelegerea şi conştientizarea mai bună, prin studierea mai aprofundată a cauzelor şi particularităților de evoluție a concepțiilor civilizaţiei umane destinate salvgardării ei, nu poate fi decât încurajată cu o şi mai mare ardoare în vederea statornicirii normelor și standardelor comportamentului politic, din moment ce termenul disponibil găsirii soluțiilor la diversele aspecte şi componente ale crizei globale este tot mai scurt, exercitând presiuni tot mai mari asupra proceselor decizionale şi de cercetare. Organizarea mai bună a societății în întregime, în concordanță cu imperativele științifice, cu principiile normative și eficientizarea impactului instituțiilor sociale atât naționale, cât și internaţionale, pentru un management mai eficace al crizei globale multidimensionale, sunt acceptate și de savanți, și de politicieni, și de opinia publică, drept căi principale de ieșire din situaţia în care s-a pomenit omenirea, dar şi ca obiective prioritare la care tind să se ralieze toate sistemele vieții sociale. Domeniul deliberărilor și dezbaterilor electorale, în virtutea locului pe care-l ocupă în funcționarea sistemelor politice democratice, la fel, are tendința de a se autoperfecționa, prin a conferi un randament mai bun implicării celor mai variate categorii și grupuri sociale în procesele elective, cu scopul de a 
identifica liderii sociali cei mai capabili și talentați în a stimula, mobiliza şi de a duce după sine alegătorii şi societatea către o dezvoltare durabilă prin educarea unui comportament politic adecvat, după cum remarcă și cercetătorul român Cristian Pîrvulescu în lucrarea sa „Politici și instituţii politice” [5, p. 75]. Nu poate trezi dubii faptul că procesele deliberative ca fenomene sociopolitice complexe cu implicații și influențe directe sau circumstanțiale într-un şir întreg de subsisteme ale sociumului implică şi sunt dependente, până la urmă, de factorul uman, de calitatea persoanelor implicate ca organizatori, ca subiecți activi în alegeri și deliberări publice, dar şi ca alegători, pe lângă aspectele cantitative și numerice, care la fel lasă o amprentă deosebită asupra eficienței procedurii deliberative. Factorul uman nu se poate manifesta în sfera publică făcând abstracție de principiile de viață ale individului uman, de comportamentul său în spațiul politice, de prioritățile sale individuale, de valorile și normele morale pe care le împărtășește, de cutumele, tradițiile, chiar și de prejudecăţile și stereotipurile iraționale aferente. În acest sens, specificul sistemului normelor morale, a modelelor etice și general-civilizaţionale au un impact profund asupra proceselor deliberative din societatea în care se produc și, implicit, asupra sistemului de norme și standarde comportamentale [6, p. 18]. În cadrul dezbaterilor sociopolitice contemporane, se atestă aducerea în prim-planul preocupărilor alegătorilor, politicienilor, a societății în ansamblu, a problematicii ajustării cadrului normativ-legislativ, cât și a cadrului politic la aspectele ce țin de condiția biologică a omului, la diversele aspecte în care problematica vieții, rolului vietății și drepturilor sale este repusă la un cu totul alt loc ca până acum, în cadrul ansamblului priorităților sociale, economice, juridice și politice. Iar cel mai definitoriu element al reorientării vectorului politicii sec. XXI constă în aceea că în rezultatul confruntărilor politice dintre năzuințele grupurilor de cetățeni care pledează pentru revederea bazelor juridice, sociale și economice ale modelului politic contemporan, deși laic dar totuși bazat pe tradițiile creștine, pe cele islamice sau iudaice, cu forțele conservatoare ale sistemului politic ce intenționează să se opună schimbărilor, dezbaterile sociopolitice capătă un cu totul alt sens din perspectiva reducerii lor la confruntarea sistemelor de valori și la argumentarea supremației modelelor morale și comportamentale.

La sfârșitul sec. XX se discuta în cercurile largi printre savanți de diverse specialități, printre cercetători din cadrul științelor sociale, din domeniul științelor economice, dar mai cu seama din sfera celor politice, despre asemenea influențe complexe care tindeau să domine în viitorul apropiat viața sociopolitică precum: digitalizarea şi computerizarea ca trenduri și extensiuni naturale ale globalizării, inclusiv în sfera exercitării puterii, în domeniul presiunilor sociopolitice sau a proceselor deliberative, așa încât după trecerea perioadei menţionate acele presupuneri şi estimări au devenit certitudini care lasă un impact adânc, mai cu seamă în cultura, comportamentul și conștiința sociopolitică, atât la nivel mondial, cât și la micro-nivel politic, referinduse nemijlocit la individul uman și anturajul său imediat
[7, p. 197]. La începutul sec. XXI însă, atenţia cercurilor ştiinţifice, a clasei oamenilor politici și a tehnocraților din diverse domenii ale economiei, este captată totalmente de subiectul priorităţilor şi potenţialului sociopolitic al comunităților umane de a face față la provocarea crizei globale multidimensionale care tot mai mult se adâncește şi se diversifică structural, fiind cauzată în mod pregnant de involuţia moralei sociale și a degradării standardelor etico-valorice ale omului contemporan. Emanciparea tot mai mare a spiritului civic şi a societăţii civile, larga utilizare şi diversificarea spectrului de metode specifice ingineriei societale şi tehnologiilor electorale folosite în lupta politică, în exercitarea puterii politice, precum și în guvernarea societății, contribuie tot mai decisiv și ireversibil la extinderea și deschiderea domeniului moralităţii sociale către noi orizonturi ideatice şi includerea în complexul contextual al dezbaterilor politice, printre cele mai consacrate și tradiţionale teme, subiecte cu specific etic, cu statut de tabu în societățile tradiţionale și provinciale [8, p. 92]. Lipsa unui cadrul normativ adecvat în domeniul securităţii umane a dus la instaurarea unor practici sociale şi politice nocive pentru stabilitatea, prosperitatea, progresul şi coeziunea societății, precum cele legate de acceptarea tacită în societatea autohtonă a unor forme de corupție, „,nepotism” sau „cumetrism”, a toleranței excesive a populației față de proasta guvernare și devierea comportamentală de la normele morale ale clasei politice și elitei sociale, indiferența și dezamăgirea electoratului, în majoritatea cazurilor, față de necesitatea implicării personale, în calitate de societate civilă, în chestiuni de interes public sau național [9, p. 47].

Pe de o parte, imperativul normativ al corectitudinii în cadrul proceselor deliberative poate deveni realizabil doar cu condiția respectării unor norme etice de către indivizii umani implicați în aceste procese. Pe de altă parte, corectitudinea alegerilor poate deveni și o condiție importantă pentru realizarea unor drepturi fundamentale pentru sistemul democratic, căci are un rol-cheie în asigurarea dreptului de vot al cetățenilor ca beneficiari și participanți în cadrul proceselor deliberative. În aşa fel, devine necesar să se respecte un set de condiții minime care să garanteze corectitudinea în alegeri și dezbateri publice. Întâi de toate, e nevoie ca toți cetățenii adulți să beneficieze de dreptul de vot în mod nediscriminatoriu. Cetățenii privați de acest drept e necesar să aibă posibilitatea să facă apel către o instanță judecătorească competentă în evaluarea unei astfel de situații, dar și în corectarea promptă și eficientă a unei eventuale erori comise de sistemul social. La fel, pentru a obține un grad satisfăcător al corectitudinii în deliberările publice, e nevoie ca participanții să beneficieze de drepturi egale pentru a-și exercita îndatoririle. Toți participanții la deliberări trebuie să beneficieze de un tratament echitabil din partea autorităților ce organizează aceste procese, iar opțiunea fiecărui participant e nevoie să fie luată în considerare în mod egal și fără distorsionări sau interpretări. Dreptul la păstrarea secretului opțiunii deliberative exprimate trebuie să fie respectat și nerestricționat în niciun fel, care totodată implică și anumite responsabilități și obligații pentru participant. Aceste condiții obligatorii pentru creșterea gradului de 
corectitudine în procesele deliberative sunt stipulate atât într-un şir de prevederi şi acte legale naţionale şi internaţionale, cât și promovate prin diverse modele deliberative și normative, ceea ce denotă o dată în plus corelația strânsă dintre normele juridice și cele morale, dar şi dintre acestea și practicile deliberative şi democratice.

Procesele electorale contemporane sunt structurate în mod complex și includ o serie de etape și stadii, depăşind substanțial limitele zilei propriu-zise a alegerilor politice. Prin urmare, fenomenul electoral este compus din alcătuirea și actualizarea listelor de alegători în care sunt incluşi cetățenii cu drept de vot; înregistrarea candidaților - etapă ce semnifică intrarea în cursa pentru ocuparea unei funcții eligibile; campania electorala propriu-zisă, care presupune promovarea candidaților și a formațiunilor social-politice care îi susțin; exercitarea efectivă a dreptului de vot - proces prin care cetățenii cu drept de vot se pot prezenta la secțiile de votare pentru exprimarea opțiunii lor electorale; centralizarea și numărarea voturilor se efectuează de către instituțiile electorale abilitate cu funcția de a organiza scrutinul şi de a administra datele adunate; validarea și publicarea oficială a rezultatelor alegerilor, ceea ce presupune anunțarea rezultatelor scrutinului.

La aceste stadii și etape se asociază și activitatea continuă de control asupra legalității tuturor aspectelor procesului electoral, funcție delegată unor instituții și organizații specializate. Controlul şi monitorizarea legalităţii procesului electoral presupune exercitarea egală și uniformă a dreptului de vot de către toți alegătorii; asigurarea egală și uniformă a dreptului de a fi ales pentru toți candidații; efectuarea monitorizării și controlului asupra procesului de finanțare a campaniilor electorale și a finanțării formațiunilor sociopolitice; asigurarea administrării de către instituțiile executive abilitate a desfăşurării echitabile şi corecte a procesului alegerilor cu referință la toți concurenții înscriși în cursa electorală; verificarea legalității rezultatului final al alegerilor.

Pentru fiecare dintre aceste etape ale procesului electoral sunt specifice un şir de imperative şi principii normativ-etice ce sunt necesare de respectat, pentru ca procesul dat să-şi atingă scopurile precizate mai sus. În acest context se remarcă astfel de principii precum: cel al echităţii față de concurenții-participanți la alegeri și alegători, al responsabilităţii participanţilor la deliberările publice, al transparenței și vizibilității desfășurării deliberărilor, al competenței cu referință la persoanele ce organizează și administrează procesul deliberativ, principiul etic al integrității sistemice cu referință la necesitatea ne admiterii destabilizării întregului sistem sociopolitic prin intermediul sau în cadrul procesului deliberativ, cel al predominării opțiunii majorității alegătorilor în procesul de adoptare a deciziei finale ca rezultat al procesului deliberativ etc.

La fel, se evidențiază o corelație organică dintre modelele sociale și diverse modalități deliberative. Astfel, spre exemplu, modelul etic tradițional determină modalitatea deliberativă directă specifică sistemului democrației directe, având anumite carențe specifice, fiind un sistem deliberativ preponderent restrictiv și exclusivist, implicând doar persoane cu un anumit statut social sau economic. Modelul etic liberal, specific perioadei industriale şi capitaliste de dezvoltare a societăţii umane, determină o extindere a drepturilor deliberative către diverse categorii de cetățeni, având tendința de a recurge la un şir de modalități deliberative informaţionale, tehnologice, impersonale și virtuale de exprimare a opțiunii votantului [10, p. 92]. Modelul bioetic se remarcă ca fiind unul caracteristic și eficient în contextul proceselor deliberativ din perioada postindustrială, în condiţiile crizei globale și a necesității imperative de a o depăși și soluționa în mod sustenabil, atunci când procesele politice, inclusiv cele deliberative, sunt subordonate, într-o anumită măsură, unui scop suprem ce stă în fața întregii societăţi, ca cel al supraviețuirii omenirii.

Procesele deliberative sunt supuse unor tendințe constante de democratizare, în virtutea unor procese globale în care valorile democratice câștigă din ce în ce mai mult teren [11, p. 352]. $\mathrm{Cu}$ toate acestea, democratizarea se reprezintă a fi un proces fluctuant și discontinuu totuși, care poate progresa, stagna sau regresa. Procesul sociopolitic al democratizării devine continuu și progresiv doar în anume condiții care întrunesc securitatea de sistem, sustenabilitatea generală a mediului sociopolitic sau / și prezența vectorului strategic către o dezvoltare durabilă a sociumului implicat în procesul democratizării, cu toate componentele sale constitutive ale comportamentului social. O condiție obligatorie a democrației sociopolitice se referă nemijlocit la procedura identificării și desemnării elitelor, a factorilor de decizii și guvernanților care exercită puterea politică în virtutea mandatului primit de la cetățeni. Pentru buna funcționare a proceselor deliberative devine fundamental de importantă libertatea deliberativă ca o condiție minimă pentru realizarea principiului democratic.

Libertatea electorală, cu cele două laturi intrinseci libertatea de a alege și libertatea de a fi ales, reprezintă de asemenea o componentă importantă a bunei desfăşurări a procesului deliberativ în cadrul unui sistem politic democratic. În epoca amplificării problemelor globale și a crizei mondiale crește nivelul de insecuritate, inclusiv de ordin politic, manifestându-se în toate sferele constitutive ale vieții politice, inclusiv în domeniul electoral, afectând în final calitatea democrației și a bunei funcționări a sistemelor sociopolitice [12, p. 83].

Nevoia de siguranță și securitate personală a omului se află printre primele sale necesități vitale, după cele biofiziologice, cum ar fi nutriția, nevoia de adăpost și supraviețuire, în piramida ierarhică a nevoilor elaborată de psihologul Abraham Maslow în 1943 [13, p. 373]. Siguranța personală transcende către siguranța fizică și teama de a fi agresat și face apel la siguranța economică și financiară: necesitatea unui venit minim garantat, siguranța locului de muncă, siguranța confortului psihic necesar activității eficiente liber de angoasele vieții de zi cu zi. De asemenea, siguranța personală se referă și la siguranța sociopolitică, prin care omul caută să viețuiască într-un sistem ierarhic confortabil, echitabil și stabil, ferit de violențele războaielor, revoluțiilor și loviturilor de stat cu reguli clare şi corecte în care poate fi posibil progresul 
şi prosperarea prin muncă cinstită, loialitate și perseverență [14, p. 93].

Perceperea insecurităţii de sistem de către cetățean poate genera astfel de distorsiuni ale comportamentului politic cum ar fi absenteismul electoral, poate amplifica efectul fenomenului votului iraţional sau poate contribui la creșterea insatisfacției generale a electoratului referitor la procesul politic de deliberare, reieșind din imposibilitatea exercitării funcției sale principale în cadrul sistemului democratic de redistribuire a puterii de stat ca urmare a blocării funcționalităţii principiului democratic de adoptare a deciziilor prin consensul majorităţii, în condițiile necesității asigurării securității sistemice prin instituirea temporară a unor corapoarte mecanicist-autoritare dintre guvernanți şi guvernaţi pentru a facilita eficiența sistemului în lupta firească cu pericolele la adresa sa [15, p. 107].

Într-un mediu nesigur libertatea deliberativă se reduce semnificativ, reieşind din necesitatea accentuării interesului comunitar ca prioritate în fața interesului individual până la anihilarea pericolelor. Deoarece, în condițiile crizei mondiale, insecuritatea politică se amplifică până la nivel global, libertatea deliberativă ca un element constitutiv al democratizării sferei politice suferă perturbații majore, fiind neglijată și redusă semnificativ.

Dată fiind amplificarea crizei globale și ameninţarea ei la adresa existenței omului pe Terra, soluţionarea problemei supraviețuirii omenirii în condiţii decente, asigurând toate premisele necesare pentru un nivel înalt de viaţă al fiecărui individ, dar şi al umanităţii în ansamblu, în perioadele ulterioare de după depăşirea crizelor ce ameninţă civilizaţia contemporană, depinde în mare măsură de găsirea unei formule funcţionale pentru stabilirea unui control social eficient, inclusiv prin diverse surse mass-media, asupra procesului de dirijare socială, mai ales în cazul procesului managerial folosind tehnologii biologice şi informaţionale avansate, la care marea majoritate a populaţiei nu are acces, spre a asigura o dezvoltare durabilă a întregii civilizaţii umane în condiţii de echitate. Astfel, se poate remarca un şir de mecanisme ce se impun a fi puse în aplicare pentru realizarea acestui deziderat, aflându-se într-o interdependenţă sistemică. Democratizarea accesului la deciziile politice şi sociale de importanţă cardinală pentru societate, fortificarea sistemului juridic şi de apărare a drepturilor şi libertăţilor omului, creşterea importanţei fundamentării ştiinţifice a procesului de guvernare şi proiectelor sociopolitice, mecanisme importante dar care pe departe sunt depăşite de rolul mediator în cadrul stabilirii unui control social eficient asupra procesului decizional din sfera sociopolitică, al fortificării şi sprijinirii mass-mediei ca a patra putere în stat şi cel al expertizării etice a proiectelor, politicilor şi strategiilor macro-sociale propuse spre a fi implementate în practica socială de către clasa politică.

În mod natural şi logic au fost deduse şi edificate un şir de noi concepţii cu privire la salvgardarea omenirii prin depăşirea impasului în care se află civilizaţia umană la etapa contemporană de evoluţie, divizată în mai multe direcţii şi abordări, în dependenţă de factorii civilizaţional şi politic. În consecință au fost evidenţiate o serie de domenii și discipline, cu caracter normativ, cu un real potenţial praxiologic și aplicativ ca mecanisme instituţionale practice cu un impact social semnificativ în procesul formării comportamentului politic al persoanei umane.

Astfel, în contextul situaţiei socioeconomice şi politice create la etapa contemporană în evoluţia omenirii, ce denotă un profund impas în care se află civilizaţia umană, apariţia şi dezvoltarea diverselor concepţii etice, în baza unor structuri şi construcţii socioculturale tradiţionale, se afirmă ca fiind o viziune progresistă, capabilă să identifice direcţii şi căi acceptabile de soluţionare a crizei globale. În aşa fel, delimitarea şi consolidarea diferitor modele etice se afirmă ca o modalitate suplimentară de formare comportamentală politică, prin diversitatea şi originalitatea potenţialului umanităţii de autoevaluare, mobilizare şi autoprotecţie în momente critice, precum este perioada actuală, dominată de pericolul şi ameninţările crizei mondiale.

Ştiinţa contemporană pare a se manifesta ca o soluție la pericolele trasate mai sus. Anume știința și tehnologiile cele mai avansate reprezintă o diversitate bine închegată de idei şi paradigme, metodologii şi construcţii teoretice, care sunt bine elaborate și gata să fie aplicate în practică, în cazul unei eventuale crize a praxisului uman şi care, în situaţii extreme, ar fi capabile să acorde un suport şi sprijin substanţial efortului lui Homo Sapiens de a găsi soluţii eficiente în perioade scurte de timp, prin educarea acestuia și formarea unor reacții politicocomportamentale adecvate. Aceasta începe să devină, şi cu timpul va reprezenta, o direcţie strategică de dezvoltare a ştiinţei viitorului. Este vorba de creşterea expresă a capacităţii ştiinţei de a fi mai mobilă, mai flexibilă, mai maleabilă şi mai deschisă posibilelor inconveniențe şi schimbări ale principiilor tradiţionale ale ştiinţei. Netradiţionalul, inventivitatea şi noutatea începe să domine gândirea ştiinţifică ca şi pe cea profană şi, peste o perioadă, inevitabil, va ajunge să fie exacerbat şi exagerat şi acest principiu ca pilon al cunoaşterii ştiinţifice al viitorului pe perioada crizei fără de precedent ce va ameninţa omenirea cu dispariţia acesteia. Erodarea pilonilor de bază, a postulatelor fundamentale cu trecerea timpului şi cu schimbarea priorităților, este tot atât de naturală și firească, în cadrul dezvoltării științei, ca şi pentru organizarea şi funcționarea corpului social, în perspectiva reformării setului de modele politicocomportamentale.

Un control social eficient poate fi impus în domeniul aplicării tehnologiilor avansate în sfera securității şi apărării prin stabilirea şi instituționalizarea obligativității expertizării etice (similar cu expertizarea etică în cercetare) a proiectelor, programelor sau proiectelor sociale, politice, ecologice sau din domeniul securităţii, cu implicații în sfera protecției integrității individuale, de grup, a statului sau regionale şi internaționale.

În concluzie, mersul și eficiența proceselor deliberative este direct corelat cu sistemul de valori sociale, cu sistemul de norme morale, dominant în societate, pe de o parte, iar pe de alta, depinde foarte mult de competența, profesionalismul şi gradul de respectare a eticii profesionale specifice funcţionarilor implicaţi în 
organizarea dezbaterilor publice precum și de moralitatea individuală şi conştiinciozitatea indusă prin educaţie și modele socio-comportamentale determinante pentru manifestările concurenţilor electorali și politici în spaţiul public, exemple de urmat ce determină şi influențează şi comportamentul alegătorilor atât în contextul proceselor deliberative, cât și în spaţiul sociopolitic, în cel mai vast sens al termenului. Prin urmare, pentru o mai mare eficiență a proceselor deliberative, prin moralizarea și aducerea lor în conformitate cu normele și standardele comune pentru comunitatea internațională, se cere un control mai strict asupra respectării normelor legale în perioada alegerilor politice și în dezbateri publice din partea organelor de stat responsabile cu organizarea şi administrarea proceselor deliberative, sancționarea juridică promptă a încălcărilor comise, pe de o parte, iar pe de altă parte, se impune o monitorizare mai temeinică, în condițiile unei transparențe echitabile și o sancționare morală, în caz de abateri, prin intermediul organelor mass-media, prin sporirea publicităţii și amplorii mediatice ale cazurilor de comportament inacceptabil, prin declanșarea unor scandaluri publice ca urmare a eforturilor depuse de diverse organisme ale societății civile.

\section{Referințe bibliografice:}

1. SPRINCEAN, Serghei; SOHOȚCHI, Tudorița-Sanda, Asigurarea securității umane prin optimizarea procesului decizional din Republica Moldova. În: MOLDOSCOPIE. Publicație periodică ştiinţifico-practică. [Chișinău]. Anul 24 (2020), nr. 4 (91), p. 73 - 80.

2. LIJPHART, Arend, Modele ale democrației. Forme de guvernare și funcționare în treizeci și șase de țări, Iași, Polirom, 2000.

3. SPRINCEAN, Serghei; SOHOȚCHI, Tudorița-Sanda; MITROFANOV, Ghenadie. Protecția și siguranța persoanelor: provocări ale securității umane în context global. In: Relații internaționale. Plus. 2021, nr. 1(19), p. 79-90.

4. OAKESHOTT, Michael, Raționalismul în politică, București, ALL, 1995.

5. PÎRVULESCU, Cristian, Politici și instituții politice, ediția II, București, Editura Trei, 2002.

6. RUSNAC, Gheorghe, Politica şi morala, in: Politica, 1991, nr. 1, p. 16-22.

7. SPRINCEAN, S.; SOHOȚCHI T.-S. Filosofia securității umane în contextul provocărilor contemporane. În: Filosofia și perspectiva umană: sustenabilitatea gândirii filosofice în societatea post-pandemie. Materialele conferinței științifice consacrate Zilei Mondiale a Filosofiei, 19 noiembrie 2020. Institutul de Istorie. / Coord. A. Pascaru. Chișinău: Tipograf. "Lexon Prim". 2020, p. 194-205.

8. SPRINCEAN, Serghei; BECCIU, Sorin, Importanța societății civile și a grupurilor de presiune pentru asigurarea securități proceselor decizionale, in: Revista de Filosofie, Sociologie și Științe Politice, nr. 2, 2017 , p. 85-98.

9. SPRINCEAN, S.; CATAN, A. Implicații securitare ale politicilor de promovare a drepturilor omului. În: Vector European. 2021, nr. 1, pp. 46-49. 2002.

10. LAKOFF, George, Moral politics. How liberals and conservatives think, Chicago, University of Chicago Press,

11. SPRINCEAN, Serghei, Tendințe în evoluția securității umane și dezvoltării durabile din Republica Moldova, in: Biodiversitatea în contextul schimbărilor climatice: Materialele conferinței științifice cu participare internațională, 25 noiembrie 2016, Chișinău / Com. șt. Maria Duca [et al.], Chișinău, Biotehdesign, 2016, p. 351-354. 2017.

12. SPRINCEAN, Serghei, Securitatea umană și bioetica. Monografie, Chișinău, F.E.P. „Tipografia Centrală”,

13. MASLOW, Abraham, A theory of human motivation, in: Psychological Review, vol. 50 (4), Jul. 1943, p. 370396.

14. SPRINCEAN, S.; BECCIU, S. Perspectiva postmodernă asupra problematicii siguranței omului în contextul provocărilor contemporane. În: Revista de științe politice și relații internaționale (Institutul de științe politice și relații internaționale „Ion I. C. Brătianu”) [București], Tomul XVIII, Nr. 2, 2021, p. 91-100.

15. BRENNAN, Geoffrey; LOMASKY, Loren, Democracy and decision: the pure theory of electoral preference, Cambridge, Cambridge University Press, 1997. 